\title{
Climate Perception, Migration and Productivity of Maize Farmers in Ghana
}

\author{
Shaibu Baanni Azumah (Corresponding Author) \\ DAAD climapAfrica Postdoctoral fellow. University for Development Studies. P. O. Box TL \\ 1882. Tamale, Ghana | Global Shea Alliance, Accra, Ghana. ORCID: \\ https://orcid.org/0000-0001-9046-5079
}

Abass Mahama

Directorate of Policy Planning, Monitoring and Evaluation-Ministry of Food and Agriculture, Accra, Ghana. ORCID: https://orcid.org/0000-0002-8533-5787

Rosaine N. Yegbemey

DAAD climapAfrica Postdoc Fellow. Department of Rural Economy and Sociology, Faculty of Agronomy. University of Parakou. Benin. ORCID: https://orcid.org/0000-0003-2051-0289)

Frederick Dapilah

Simon Diedong Dombo University of Business and Integrated Studies, Department of Community Development, Wa-Upper West Region, Ghana. ORCID: https://orcid.org/0000-0002-3215-7104

Received: December 14, 2021

doi:10.5296/jas.v10i1.19494
Accepted: January 14, 2022 Published: January 22, 2022

URL: https://doi.org/10.5296/jas.v10i1.19494

\begin{abstract}
High temperature, erratic rainfall, and drought are the three major physical manifestations of climate change in Ghana. Smallholder farmers in Ghana have shown vulnerability to the impacts of climate change, with some farmers employing migration as an adaptation mechanism. Using primary data collected from 500 maize farmers in seven districts of Ghana, our study draws a link among climate perception, migration and productivity of maize farmers by estimating a two-step Heckman sample selection model and employing inductive coding to analyse the qualitative data. The results show that farmers' experience, access to farm credit, farm size, location, usage of NPK fertilizer, and local seeds have positive impact on the productivity of maize farmers. Additionally, household size, main occupation, membership in farmer-based organisations, and perception of declined soil fertility have significant effects on migration decisions of smallholder maize farmers. The qualitative reports show that perceived increase in temperature, drought, flooding, and erratic rainfall has led to a decline in the
\end{abstract}


productivity of maize farmers. Among others, we recommend that relevant stakeholders (i.e., policy makers and NGOs in the agricultural space) should focus on promoting the use of improved seeds, and NKP fertilizer, coupled with the provision of farm credit and expansion of farm sizes to enhance the productivity of maize farmers in Ghana. Also, smallholder farmers should be supported to engage in alternative livelihood enterprises, join farmer-based organisations and to adopt techniques that enhance soil fertility in order to reduce climate-induced migration among maize farmers.

Keywords: Heckman, Ghana, climate change, productivity, maize farmers

\section{Introduction}

Many empirical studies confirm the adverse impacts of climate change in Sub-Saharan Africa (SSA), increasing the vulnerabilities of many countries (Niang et al., 2014). According to Gbangou, et al. (2020), high temperature, erratic rainfall, and prolonged dry spells are the three main physical manifestations of climate change in Ghana. The threats from climate change are already having significant effects on the livelihoods of many people, with the agriculture sector increasingly threatened by the changing climate (Nelson et al., 2009). Climate change exacerbates the deterioration of agricultural system, resulting in decreased farm outcomes and livelihood opportunities among rural folks which could result in food insecurity, poverty, and migration (FAO, 2017). However, studies that link climate perception, migration, and productivity are non-existent.

Majority of smallholder farmers in SSA are poor with less adaptive capacity to climate change (Fisher et al., 2015), and depend heavily on rainfed agricultural systems for the production of crops such as maize (Di Falco, 2014). According to Adimassu et al. (2014), maize production in SSA is still at the subsistence level, meaning that farmers consume most of what they produce and sell the surplus to cater to their household needs. However, rising temperature coupled with erratic weather conditions such as floods and drought, all emanating from climate change is expected to significantly affect productivity of maize farmers (Sutcliffe et al. 2016).

In Ghana, climatic change has manifested through increased temperature, drought, and flooding events in the last 40 years (Asante and Amuakwa-Mensah, 2015), increasing the vulnerabilities of smallholder farmers just as in many other countries in Africa, south of the Sahara (Bawakyillenuo, Yaro and Teye, 2014). Ghana has a diverse cropping system, spread across different ecological zones (Srivastava et al., 2018), reflecting the need for context-specific adaptation mechanisms to address the impacts of climate change on cropping systems (Williams, Crespo and Abu, 2019).

Smallholder production has been identified as an important source of income by providing many poor households with employment opportunities in Ghana (Abdulai et al., 2017). Smallholder farmers' perceptions of climate change in the rainfed agricultural systems are important in understanding their response to climate change (Snaibi et al., 2021). For that matter, Maddison (2007) asserted that smallholder farmers with the cognitive ability to perceive changes in climatic events are often more prepared to tackle threats from climate change. Smallholder farmers in SSA have proven to be innovative and dynamic in combating 
the effects of climate change, several adaptation strategies including improved crop varieties, soil and water conservation measures, early planting, diversification of livelihood, chemical fertilizer use, etc. are used by smallholder farmers (Adzawla et al., 2019). Other measures such as agriculture intensification, agroforestry, planting drought-tolerant varieties, and migration were also found to be popular among many smallholder farmers in Ghana (Antwi-Agyei, Stringer, Dougill, 2014; Bawakyillenuo, Yaro and Teye, 2016; Codjoe, Owusu and Burkett, 2012).

Migration has been a climate change adaptation strategy for many smallholder farm households in SSA. According Jawura (2013), migration is the second most important coping strategy of most households in northern Ghana in response to the negative effects of climate change. For Nicholas, Dugle, and Darius (2017), migration remains one of the most crucial strategies that is central to a host of adaptation strategies used by many farmers in resource poor areas in Ghana. Migration involves the movement of a group of people or individuals from their home origin to new settlements due to adverse impacts of demographic factors (Kallio, 2016), economic factors (Mihi-Ramirez and Kumpikaite, 2014) and environmental factors (Milán-García et al., 2021) or a combination of all (Kok et al., 2003).

Climate change affects the livelihoods of individuals and households through its implications on agricultural productivity, hence increasing their incentives for migration (Waldinger and Fankhauser, 2015). Migration as a climate adaptation strategy is not new in climate change adaptation studies. It is widely agreed that migration presents itself as a positive beneficial climate change adaptation strategy (Bardsley and Hugo, 2010). The effects of climate change and migration on farm productivity of smallholder farmers in Ghana and in sub-Saharan Africa (SSA) at large, cannot be overlooked. While the impact of climate change on agriculture is well documented in literature (Azumah et al., 2021; Williams et al., 2019), the nexus between climate change, migration, and their consequences on maize production have not been adequately assessed and documented, hence, the need for this study. Empirical evidence shows that labour force in developing countries is likely to respond to climatic change by migrating for greener pastures. However, there is less evidence on the relationship between climate change, migration, and the productivity of maize especially in the Ghanaian context. This study was therefore conducted to determine how migration and perception of climate change impact the productivity of maize farmers in Ghana. The rest of the paper is organised as methodology, results and discussions, conclusions and policy recommendations.

\section{Study area and Methodology}

This section outlines the technical approach for conducing this study. It highlights the characteristics of the study area, sampling process and data collection, and tools for data analysis and interpretation.

\subsection{Study Area}

The study was conducted in seven districts of Ghana: Sissala East, Kintampo, Wiaso, North Gonja, Nkronza, Juaboso, and Gushiegu. These districts were purposely selected because of the concentration of maize production and their vulnerabilities to the effects of climate change. 
The districts were then put into their respective region for easy identification and to ensure ecological representativeness: Kintampo and Nkoranza representing Bono East region; Gushegu from Northern region; North Gonja from Savannah region; Wiaso and Juaboso from Western North region. Consequently, the regions were further categorized into two zones i.e., Northern (Upper West, Savannah, and Northern regions) zone and Southern Zone (Bono East and Western North regions). The agro-ecological nature of the Northern Zone makes it particularly suitable for livestock production because of the vast grassland and also good for the production of major cereals and legumes such as maize, groundnut, rice, cowpea, and soybean. Some smallholder farmers in the Northern zone practice some mixed farming systems notwithstanding the extreme weather events prevailing in the zone. The Northern zone is characterized by a short rainy season and a long period of dry conditions with its accompanying high temperature (Ghana Statistical Service, GSS, 2013). Yearly floods have become a common feature in this part of the country. Despite these extreme weather conditions, Maize is widely cultivated in the Northern Zone amid fears of crop failure. The Southern zone comparatively has some favourable weather conditions despite increasing threats of climate change. The Southern zone of Ghana experiences a bi-modal rainfall pattern and currently experiencing erratic dry spells and occasional flooding. The zone is particularly suitable for the production of cereals (maize, rice), root and tuber crops (yam, cassava, cocoyam), fruit tree crops (citrus, mango), and other industrial tree crops (cashew, cocoa, rubber) (GSS, 2013).

\subsection{Sampling and Data Collection}

Both quantitative and qualitative data were collected using structured questionnaires, key informant checklists, and focus group discussion (FGD) guides. 500 maize farmers selected from the five regions made up the sample for the quantitative data (meaning, 100 farmers from each of the regions were interviewed). In each of the study districts, 50 to 100 maize farmers were randomly selected. Qualitative data were collected through key informant interviews with experienced maize farmers (migrants and non-migrants) and opinion leaders within the study districts. Also, five FGDs were conducted in Juboaso, Kintampo, Nkoranza, Wiaso, and Sissala East districts, to obtain more information on climate perception among migrant and non-migrant maize farmers.

\subsection{Data Processing and Analysis}

In this study, Propensity Score Matching (PSM) was first used to account for confounding bias (observed biases) among migrant and non-migrant groups of maize farmers. The propensity scores were calculated for each maize farmer and had a probability ranging from 0 to 1 , specifying which group or condition a maize farmer belonged to (migrant or non-migrant) on a particular set of restrained variables. The study sample was reduced to 492 after executing the PSM, meaning, only maize farmers with propensity scores were included in the Heckman two-stage selection model for analysis.

Data were analysed both qualitatively and quantitatively. Qualitative analysis of data from focus group discussion and key informant interviews were done using the inductive coding method, which allowed for participants' responses on climate perceptions to be summarized into forms that can easily be understood. Quantitative data from individual household surveys 


\section{Macrothink

were analysed inferentially using Heckman's two-stage sample selection model.

The Heckman selection model (Heckman, 1976) was used to analyse the relationship among migration, perception about climate change, and the productivity of maize farmers in Ghana. The Heckman two-stage sample selection model follows a two-equation model. There is the treatment (substantive) equation as stated in equation 1.

$$
y_{i}=x_{i} \beta+\mu_{1}
$$

The selection equation model is stated by equation 2 .

$$
s=z_{i} \gamma+\mu_{2}>0
$$

The error terms hold the distributions stated by equations 3a-3c):

$$
\begin{gathered}
\mu_{1} \sim N(0, \sigma) \\
\mu_{1} \sim N(0,1) \\
\operatorname{corr}\left(\mu_{1}, \mu_{2}\right)=p
\end{gathered}
$$

In the treatment model:

- $y_{i}$ represents the dependent variables.

- $x_{i}$ represents the observable characteristics of the independent variables.

- $\quad \beta$ represents the parameters to be estimated in the treatment model.

- $\mu_{1}$ is a normally distributed error term which has a zero mean and $\sigma$ as standard deviation.

In the selection equation:

- $z_{i}$ shows the observable features which covers the overlapping variables

- $x_{i}$, and Zi represents the vectors of parameters to be estimated.

- $\mu_{2}$ is a distributed error term with a mean of zero and a standard deviation equal to one (1). 
- $\quad p$ is the correlation between the two error terms to be estimated.

In the substantive equation of this study, it was assumed that the treatment equation model is used to explain maize productivity as depicted by equation 4 :

$$
y_{i}=x_{1 i} \beta_{1}+C_{i} \beta_{2}+\mu_{i}=X_{i} \beta+\mu_{i}
$$

Where productivity of maize was denoted as $y_{i}$; a vector of observable features related to climate perception was denoted as $x_{i}$ in which $x_{1 i}$ represents the endogenous variables; $C_{i}$ denoted the exogenous variables; $\beta_{1}, \beta_{2}$, and $\beta$ were estimated as vectors of parameters $x_{1 i}, C_{i}$ and $X_{i}$.

$\mu_{i}$ is a normally distributed error term which had zero mean and a standard deviation of represented as $\sigma$. Here, the dependent variable $y_{i}$ may not always be observed, and it is especially observed only when the productivity of maize is influenced by climate perceptions and other covariates. Therefore, in the selection equation model (i.e., productivity of maize farmers), the dependent variable was observed if:

$$
Z_{1 i} \gamma_{1}+C_{i} \gamma_{2}+\delta_{i}=Z_{i} \gamma+\delta_{i}>0
$$

where $Z_{i}$ is a vector of observable features related to climate perception, which included the overlapping variables with $C_{i}$; $Z_{1 i}$ representing the endogenous variables that may or may not be the same as $x_{1 i} ; \gamma_{1}, \gamma_{2}$ and $\gamma$ are vectors of the parameters that were estimated; $\delta_{i}$ is a distributed error term with a mean of zero and a standard deviation equal to one. This equation described the probability that climate perception was greater than zero. The error terms held the following distribution:

$\mu_{i} \sim N(0, \sigma)$

$$
\delta_{i} \sim N(0,1)
$$

$\operatorname{corr}\left(\mu_{i}, \delta_{i}\right)=p$

where $\rho$ denoted the correlation between the two error terms that were estimated. The parameter $\lambda=\sigma \rho$, known as the inverse Mills ratio was estimated as selection coefficient. 
The estimation of the Heckman selection regression started from the selection model. In the first step, the probit regression was used to model the sample selection process in equation 5 . Next, the inverse Mills ratio $\lambda$ (the error from the probit equation explaining selection) was computed based on the probit regression results.

In the second step, the inverse Mills ratio was added to regression analysis as an independent variable, with the ordinary least square (OLS) used to provide a consistent parameter estimates in equation 4.

\section{Results and Discussions}

In section 3, we present and discuss the summary statistics of the variables used in the econometric model. The section also presents empirical findings and discussions on the impact of climate perception and migration on maize productivity, and smallholder farmers' perception of climate change in Ghana.

\subsection{Summary Statistics of Variables}

The results in Table 1 below presents the definitions and summary statistics of the explanatory variables included in the model. Maize farmers on average have 15 years of farming experience. This result is expected to have a positive effect on maize productivity among respondents. About $71 \%$ of the maize farmers were males while $29 \%$ represented female maize farmers. Also, the average age of maize farmers was 42.6 years, indicating an active adult working group. About $38 \%$ of the maize farmers were from southern Ghana while $62 \%$ were from northern Ghana.

Maize farmers had an average household size of 7.9 exceeding the national average of 3.6 persons per household (GSS, 2021). About $17 \%$ of maize farmers targeted had no access to farm credit. Farm Credit is an influencer in farmers' access to key production inputs. Access to farm credit could improve access to productive inputs. Thus, resulting in higher productivity. The credit variable is expected to have a positive relationship with productivity. The main occupation of most (94\%) maize farmers is farming. Relatively, about $22 \%$ of maize farmers are members of farmer-based organisations.

Also, maize farmers cultivate an average farm size of 5.84 acres. Surprisingly, maize farmers applied about $426 \mathrm{~kg}(8.52 \mathrm{bags}$ of $50 \mathrm{~kg})$ of NPK ${ }^{1}$ on an average farm size of 5.84 acres. This means that on average farmers are applying an average of 1.45 bags or $72.9 \mathrm{~kg}$ of NPK on an acre of farmland. This is far below Ghana's Ministry of Food and Agriculture recommended rate of 3 bags or $150 \mathrm{kgs}$ of NPK per acre. Improved seed use among maize farmers was low as shown in table 1.

An average of $13.06 \mathrm{~kg}$ of improved seeds was used by maize farmers on an average farm size of 5.84 acres. This implies that maize farmers used an average of $2.23 \mathrm{~kg}$ of improved per acre. The low NPK fertilizer and improved seed use among maize farmers may be attributed to either unavailability or the high cost of inputs. This result shakes the core of the planting for food jobs initiative, which aims at making inputs available, accessible and affordable for smallholder

\footnotetext{
${ }^{1}$ NKP Means Nitrogen-phosphorus-potassium
} 
farmers to procure.

Similarly, farmers used an average quantity of $223.77 \mathrm{~kg}$ or 4.47 bags of urea on an average farm size of 5.84 acres. This translates to an average of 1.3 bags or $65 \mathrm{~kg}$ of urea per acre. Further to this, maize farmers used about $17.57 \mathrm{~kg}$ of local seed for production. This means that farmers use an average of $3 \mathrm{~kg}$ of local seed per acre. This has an expected negative effect on productivity.

The result (Table 1) reveals that about $38 \%$ of maize farmers captured in this study are from the south. Most maize farmers rely largely on family labour for farm work. Maize farmers use an average of 5 household members for farm work compared to an average of 3 hired labour used. Most $(85 \%)$ maize farmers perceived soil fertility to have decreased.

Table 1. Definition and summary statistics of variables

\begin{tabular}{|c|c|c|c|}
\hline Definition of variables & $\begin{array}{c}\text { A priori } \\
\text { expectation }^{2}\end{array}$ & Mean & Std. Dev. \\
\hline Sex (dummy: 1 if male, 0 if female) & $+/-$ & 0.71 & 0.020 \\
\hline Age (in years) & + & 42.69 & 0.58 \\
\hline $\begin{array}{l}\text { Main occupation (dummy: } 1 \text { if farming, } 0 \text { if } \\
\text { otherwise) }\end{array}$ & $+/-$ & 0.94 & 0.0104 \\
\hline $\begin{array}{l}\text { Household size (number of dependents in a } \\
\text { household) }\end{array}$ & $+/-$ & 7.98 & 0.207 \\
\hline Location (dummy: 0 if northern, 1 if southern) & $+/-$ & 0.38 & 0.021 \\
\hline Experience (Number of years in maize farming) & + & 15.23 & 0.54 \\
\hline Membership of FBO (dummy: 0 if No, 1 if yes) & + & 0.22 & 0.018 \\
\hline Access to credit (dummy: 0 if No, 1 if yes) & + & 0.174 & 0.0174 \\
\hline $\begin{array}{l}\text { Access to extension services (dummy: } 0 \text { if No, } 1 \text { if } \\
\text { yes) }\end{array}$ & + & 0.44 & 0.22 \\
\hline $\begin{array}{l}\text { Benefit from climate-smart training (dummy: } 0 \text { if No, } \\
1 \text { if yes) }\end{array}$ & + & 0.32 & 0.021 \\
\hline $\begin{array}{l}\text { Farm size (total number of acres cultivated by a } \\
\text { farmer) }\end{array}$ & + & 5.84 & 0.27 \\
\hline NPK (total quantity $(\mathrm{kg})$ of NPK applied by a farmer) & + & 426.93 & 37.54 \\
\hline Urea (total quantity $(\mathrm{kg})$ of urea applied by a farmer) & + & 223.77 & 68.89 \\
\hline Location (dummy: 0 if northern, 1 if southern) & $+/-$ & 0.38 & 0.021 \\
\hline $\begin{array}{l}\text { Local seed (total quantity (kg) of local seed used by a } \\
\text { farmer) }\end{array}$ & - & 17.57 & 1.39 \\
\hline Improved seed (total quantity $(\mathrm{kg})$ of improved seed & + & 13.06 & 2.27 \\
\hline
\end{tabular}

2Expected sign or direction of the variable 


\begin{tabular}{|c|c|c|c|}
\hline used by a farmer) & & & \\
\hline $\begin{array}{l}\text { herbicide (total quantity (liters) of herbicide used by a } \\
\text { farmer) }\end{array}$ & + & 8.66 & 0.55 \\
\hline $\begin{array}{l}\text { Insecticide (total quantity (liters) of insecticide used } \\
\text { by a farmer) }\end{array}$ & + & 2.87 & 0.20 \\
\hline $\begin{array}{l}\text { Perception of flood (dummy: } 1 \text { if increased, } 0 \text { if } \\
\text { otherwise) }\end{array}$ & - & 0.65 & 0.021 \\
\hline $\begin{array}{l}\text { Perception of drought (dummy: } 1 \text { if increased, } 0 \text { if } \\
\text { otherwise) }\end{array}$ & - & 0.56 & 0.022 \\
\hline $\begin{array}{l}\text { Perception of pest and diseases (dummy: } 0 \text { if } \\
\text { increased, } 1 \text { if decreased) }\end{array}$ & - & 0.22 & 0.018 \\
\hline $\begin{array}{l}\text { Perception of soil fertility (dummy: } 0 \text { if increased, } 1 \text { if } \\
\text { decreased) }\end{array}$ & - & 0.85 & 0.015 \\
\hline $\begin{array}{l}\text { Family labour (number of family members engaged in } \\
\text { farm work) }\end{array}$ & + & 5.14 & 1.62 \\
\hline $\begin{array}{l}\text { Hired labour (number of people hired to engage in } \\
\text { farm work) }\end{array}$ & + & 3.35 & 0.175 \\
\hline $\begin{array}{l}\text { Migration status (dummy: } 1 \text { if migrant, } 0 \text { if } \\
\text { non-migrant) }\end{array}$ & $+/-$ & 0.57 & 0.495 \\
\hline
\end{tabular}

\subsection{The Relationship Among Climate Perception, Migration and Productivity of Maize} Farmers in Ghana

Productivity of maize in Ghana is influenced by several factors. These factors can range from environmental, economic, social, and political. This study examined the effects of climate perception and migration on productivity of maize farmers using the Heckman two-stage selection model. In all, 31 explanatory variables were included in the model. Twenty-one and ten variables were included in both the outcome and selection equations respectively. A model diagnostics test performed backs the appropriateness of the Heckman two-stage selection model in elucidating the magnitude to which the explanatory variables influence productivity of maize farmers. The Wald chi-square is significant at $1 \%\left(\mathrm{Prob}>\mathrm{Chi}^{2}=0.0000\right)$, suggesting that the explanatory variables conjointly explained the differences in the factors that impact productivity of maize farmers. The results in Table 2 present estimates of the outcome equation (maize productivity) and selection equation (migration status).

We first present the factors which influenced the migration (selection equation) of maize farmers. Household size was significant at $1 \%$ but negatively correlated with migration status. This means that maize farmers with large household sizes are more likely to be non-migrants. This result may be attributed to labour demands of a household and the fact that having large households will support the execution of farm work. This is particularly important for households that cultivate large farm sizes and earn substantial income from their farm. As asserted by Gebre, Isoda et al. (2021), households in rural areas rely largely on family labour for farm work because of limited access to hired labour. Large household sizes can keep pace 
with labour demands of their production and as such can execute farm activities timely. Thus, impacting positively on their yields.

Also, the main occupation was significant and positively related to migration status. Implies, farmers who take farming as their main occupation are more likely to be migrants. This was expected because farmers who take farming as their main occupation have their livelihoods depend on farming and its associated benefits, as such, any threat to their livelihood such as climate change threats may cause them to migrate to new environments as means to cope. In this circumstance, farmers may see migration as a coping strategy.

Membership in a farmer-based organisation (FBO) was found to have a significant but negative effect on migration status. This means that members of FBOs are more likely to be indigenes. Relatively reasonable to expect this result because such groups may be long-standing groups that probably come with stringent membership access, as such making it difficult for new members (migrants) to join. Also, some groups are formed based on the familiarity of members, this may pose difficulty for migrants to join since they are often regarded as strangers.

Perception of changes in soil fertility was found to have a significant and positive relationship with migration status. This result would imply that maize farmers with an increased perception of decline in soil fertility are most likely to be migrants. This was expected because maize plays a dual role as an income generator and food security crop in Ghana. Also, most farmers captured in this study consider maize farming as their main occupation. This means that maize farmers have their livelihoods dependent on farming. As such, decline in soil fertility that could potentially affect productivity will result in migration to new environments where soil fertility is good.

The productivity function revealed that except for famers perception on rising pest and disease infestation, all the four climate change perception predictors had negative and no significant relationship with productivity. The experience variable (maize farming) showed a significant and positive association with productivity. This means that maize farmers with added years of experience have a higher probability of achieving higher productivity than those with fewer years of experience. This can be explained by the fact that experienced farmers know their environments well and the kind of practices that improves their production and therefore will continuously improve their production practices by seeking more information and training on improved production practices. This finding is consistent with a prior expectation of positive effect and similar to findings of Mwalupaso et al. (2019); Sapkota and Joshi (2021), and Ali, Xue-xi et al. (2019) who found a significantly positive effect of farming experience with productivity of maize farmers. The authors argue that added years of experience increase the expected skill of the maize farmer since they learn by doing and that experienced farmers are effective and allocate farm resources better.

Similarly, access to credit had a positive and significant effect on productivity. This means that credit access increases the probability of achieving higher productivity. This is because credit availability increases the purchasing power of farmers and as such are better able to procure inputs that will increase their productivity (see Mabe et al., 2018). Again, the result meets a prior expectation of a positive relationship. Similar results of this study corroborate with Belete 
(2020), Lin et al. (2019), and Siaw et al. (2021). The authors found a significant and positive relationship between credit and productivity. They assert that farmers' access to farm credit empowers them to pay for productive inputs and invest in resources that improve the long productivity of their farm.

Consistent with the findings of Khanal et al. (2018), Roco et al. (2017), Konja et al. (2019), Abdulai et al. (2018) and Adzawla and Alhassan (2021), farm size had a positive and significant relationship with productivity. This indicates that an increase in productivity can be more likely when farm size increases. In Ghana, over $80 \%$ of farming is done by smallholder farmers with minimal or no mechanisation. Smallholder farmers cultivate an average farm size of less than 2 ha, thus, resulting in lower productivity. Nonetheless, the result found in this study suggests that when farmers invest more in productive land expansion, higher productivity could be achieved. However, the study diverges from Ugbagbe et al. (2017) who found a negative effect of farm size on soybean output in Kano State. They attribute this relationship to high plant density per unit farm area. Their findings limited the capacity of farmers to manage large faces especially in the face of minimal utilization of agricultural machinery. Output loss resulting from delayed harvest can gravely impact the overall output of maize.

Location was found to have a significant and positive effect on productivity. This result suggests that maize farmers in the South have higher productivity than farmers in the North. This result was expected because given the differences between the North and South in terms of climate change impacts, access to infrastructure, income differentials, etc. The gravity of these differences is contained in a study by Scheiterle and Birner (2018), where they affirm that poorly developed infrastructure, limited natural resources, relatively uneducated farmers, low income, unimodal rainfall pattern, and high impact of climate change are more aligned to northern Ghana. Low-income constraints farmers' access to key production inputs like fertilizer and improved seed.

Bad road networks and poor communication networks also affect farmers' access to extension services/agricultural information, inputs, etc. Also, inefficiencies in the input distribution system, smuggling, political forces, and hoarding of inputs are a major hindrance to farmer access to key inputs especially in Northern Ghana (Scheiterle and Birner, 2018).

NPK application was highly significant and positively related to productivity. This implies that when farmers increase the quantity of NPK applied, the likelihood of attaining higher productivity is high, corroborating with Toungos (2019); Bua, Mejahed et al. (2020), and Scheiterle, Häring et al. (2019). This result was expected since NPK is key nutrient elements for optimal maize growth. Decline in fertility of soils in Ghana especially in the North makes fertilizer (NPK) use, a necessity if farmers are to keep afloat with sustained yields. As reported in the summary statistics (see table 1), the quantity of NPK fertilizer used by maize farmers is far below the recommended rates, chronic challenges such as availability, accessibility, and affordability may be limiting farmers' use of NPK fertilizer. In fact, Abdulai et al. (2018) found a negative association of fertilizer and crop productivity. The authors finding may be attributed to the inefficiencies in fertilizer use, hence, this expected result. Thus, policy action or 
enforcement of distribution plans by the government is highly recommended so that smallholder farmers can also access this key input.

Local seed use showed a significant (10\%) and positive correlation with productivity. This would mean that farmers an increase in the quantity of local seed use has the likelihood of impacting productivity. This result is rather surprising because extensive studies show a weak relationship between local seed use and crop productivity (Abro, Debela, \& Kassie, 2019; Kassa, Tarekegn and Mogiso, 2020; Ngango \& Hong, 2021). While this result may come as a surprise, a plausible reason for the positive effect of local seeds could be that they are well adapted to local growing conditions.

The effect of improved seed usage on crop productivity has been discussed extensively in several studies (Teklewold, Kassie, \& Shiferaw, 2013; Manda, Alene, et al., 2016; Bezu et al., 2014; Khonje et al., 2015; Walker \& Alwang, 2015; Evenson \& Gollin, 2003; Suri, 2011; Abro, Dabela $\&$ Kassie, 2019). This study examined the effect of improved seed use on productivity in Ghana. The results as shown in table 2 connotes that improved seed use was very significant and exhibited a positive relationship with productivity. This would imply maize productivity will increase when there is an increased use of improved seed. The finding is in sync with studies like Abro, Debela, and Kassie (2019); Meughoyi (2018); Anang (2018), and El-Sanatawy et al. (2021), who found that improved seed use increases farmer's productivity as compared with local or recycled seeds. However, inefficiencies in the use of improved seeds may lead to lower productivity. It is therefore imperative for smallholder farmers as well as the government to facilitate the efficient use of improved seeds to achieve the desired outcome.

Family labour was found to have a positive relationship with productivity. This suggests that the productivity of maize increases when more family labour is engaged. This result is contrasted by Mwalupaso et al. (2019), who asserts that an increase in family labour lowers the productivity of maize because there will be an inequitable distribution of labour and the assigned responsibilities may not be executed efficiently. However, other studies like Gebre, Isoda et al. (2021); Oyetunde-Usman and Olagunju (2019) and Konja et al. (2019) validate this study; the authors found a positive correlation between family labour and productivity. Gebre, Isoda, et al. reports that rural households that are unable to afford the services of hired labour depend largely on family labour and this has shown a positive impact on their farm productivity. The use of family labour has an incremental impact on productivity because they are the beneficiary of farm income and food supplies. They are more productive because of lower costs associated with engaging them i.e., supervision and labour charges. 


\section{Macrothink}

Journal of Agricultural Studies

ISSN 2166-0379 2022, Vol. 10, No. 1

Table 2. Results from Heckman sample selection model (two-step)

\begin{tabular}{|c|c|c|}
\hline Variable & Coefficient & Standard error \\
\hline \multicolumn{3}{|l|}{ Output } \\
\hline Sex of respondent & 91.00141 & 961.4251 \\
\hline Household size & -128.9098 & 143.5429 \\
\hline Maize farming experience & $75.18416^{* *}$ & 35.92351 \\
\hline Member of FBO & 423.2371 & 1323.62 \\
\hline Access to farm credit & $4633.246^{* * *}$ & 1101.394 \\
\hline Access to agric. Extension service & -937.5431 & 1098.576 \\
\hline Benefit from climate-smart agricultural training & 1627.677 & 1135.762 \\
\hline Farm size & $471.4736 * * *$ & 111.6936 \\
\hline Location & $1900.061 *$ & 1171.624 \\
\hline Quantity of npk50kg & $2.458294 * * *$ & .8852356 \\
\hline Quantity of urea $50 \mathrm{~kg}$ & 0.0577786 & .2641567 \\
\hline Quantity local seeds & $88.47697 * * *$ & 13.06491 \\
\hline Quantity of improved seeds & $-14.19094 *$ & 7.606508 \\
\hline Quantity of Herbicides & 0.8758676 & 43.16874 \\
\hline Quantity of Insecticides & -75.17388 & 92.19843 \\
\hline Perception of floods & 1367.217 & 961.5033 \\
\hline Perception of drought & -347.1918 & 909.2728 \\
\hline Perception of pests and diseases & 838.5896 & 894.3639 \\
\hline Perception of soil fertility & -176.7754 & 1359.363 \\
\hline Family labour & $-14.5932 * *$ & 7.719166 \\
\hline Hired labour & 24.3008 & 118.9815 \\
\hline Constant & -2763.476 & 2958.517 \\
\hline \multicolumn{3}{|l|}{ Migrants } \\
\hline Age of respondent & 0.0017553 & .0050486 \\
\hline Sex of respondent & -0.1219653 & .14451 \\
\hline Household size & $-.0488079 * * *$ & .0133142 \\
\hline Main occupation & $0.834198 * * *$ & .2738173 \\
\hline Marital status & -0.1653394 & .1209026 \\
\hline
\end{tabular}




\begin{tabular}{l|c|c}
\hline Member of FBO & $-0.2578757^{*}$ & .1491008 \\
\hline Location & -0.1937418 & .1405656 \\
\hline Perception of floods & 0.1445044 & .1294454 \\
\hline Perception of drought & 0.0715941 & .1327904 \\
\hline Perception of soil fertility & $0.3054961^{*}$ & .1729212 \\
\hline Constant & -0.2942805 & .3799415 \\
\hline Wald chi ${ }^{2}(21)$ & 447.35 & \\
\hline Prob> chi ${ }^{2}$ & 0.0000 & 3877.236 \\
\hline Lambda & 4708.674 & \\
\hline Rho & 0.70290 & \\
\hline Sigma & 6698.9049 & \\
\hline$N$ & 492 & \\
\hline
\end{tabular}

Note: $* * *$, and $* * *$ represent statistical significance at $10 \%, 5 \%$, and $1 \%$ respectively

Source: Computed from field data, 2021

\subsection{Smallholder Farmers' Perception of Climate Change}

It is widely acknowledged that for farmers to effectively respond to climate change, they must have information on climate and climate risk events (Deressa et al., 2009; Orlove et al., 2010). In this study, we collected qualitative data through key informant interviews and focus group discussions to ascertain smallholder farmers' perceptions about climate change. Participants in both focus group discussions and key informants' sessions expressed their understandings of some observed changes in the climate in Ghana over the past few years. In all, the focus group discussion and key informant interviews participants reported four extreme weather events that have experienced some changes over the last few years. These included high temperature, torrential rainfall, drought, and flooding. Table 3 summarizes the responses of participants about their perception of climate change.

As reported by participants across the study districts, the temperature has increased over the period with nights and days becoming extremely hot. The participants noted that increased temperature has consequently affected the performance of their maize crops and also led to the drying of their streams and dams. A similar finding has been reported by Antwi-Agyei and Nyantakyi-Frimpong (2021), who found that farmers in northern Ghana perceive the temperature to have increased in a way that affects the livelihoods of people such as increased disease conditions, low crop productivity, and drying of water bodies.

Also, irregular rainfall patterns were reported by participants in both key informant interviews and focus group discussions. The inability of farmers to adequately predict the rainfall pattern had consequential effects on their productivity of maize. Again, a similar finding by Antwi-Agyei and Nyantakyi-Frimpong (2021) opined that erratic rainfall as perceived by both 
women and men contributed significantly to poor crop yields.

Again, smallholder farmers' perception of flooding shows an increase and this is impacting negatively on their productivity. Reported impact during the focus group discussions revealed that floods contributed significantly to the loss of crops and properties. Similar assertions were made during the key informant interviews as participants noted the destruction of crops and farmlands as a result of flooding.

Table 3. Smallholder farmers perception of climate change

\begin{tabular}{|c|c|c|c|}
\hline $\begin{array}{l}\text { Observed } \\
\text { changes in } \\
\text { Climatic } \\
\text { conditions }\end{array}$ & Statements by farmers & $\begin{array}{c}\text { Impacted reported } \\
\text { by farmers in FGDs }\end{array}$ & $\begin{array}{l}\text { Impacted reported } \\
\text { by key informants }\end{array}$ \\
\hline $\begin{array}{l}\text { Increased } \\
\text { temperature }\end{array}$ & $\begin{array}{l}\text { "The temperature has increased. It is } \\
\text { not like what we used to experience. } \\
\text { During the day the weather is very hot } \\
\text { and nights are unbearable as we have } \\
\text { to come out of our rooms to sleep. Our } \\
\text { crops are also drying up very fast } \\
\text { since the rains have been delayed in } \\
\text { recent times. Likewise, our streams } \\
\text { and dams are equally drying" }\end{array}$ & $\begin{array}{l}\text { Drying of streams } \\
\text { and dams. } \\
\text { Crop failure. }\end{array}$ & $\begin{array}{l}\text { Drying of streams and } \\
\text { dams. } \\
\text { Crop failure. }\end{array}$ \\
\hline Irregular rainfall & $\begin{array}{l}\text { "Unlike some years ago, we can no } \\
\text { longer predict the timing of rainfall. } \\
\text { Rainfall has reduced drastically and } \\
\text { no longer comes early. Rainfall } \\
\text { duration has decreased and rains for } \\
\text { a short period and stops. This affects } \\
\text { our crops since they do not get } \\
\text { enough water to grow and our dams } \\
\text { also dry up fast since the rains do not } \\
\text { have much" }\end{array}$ & $\begin{array}{l}\text { Travel long distances } \\
\text { in search of water. } \\
\text { Low crop } \\
\text { productivity. }\end{array}$ & $\begin{array}{ll}\text { Low } & \text { crop } \\
\text { productivity. }\end{array}$ \\
\hline Prolong drought & $\begin{array}{l}\text { "The wet season is gradually } \\
\text { becoming shorter and dry periods } \\
\text { longer. Drought conditions are } \\
\text { affecting our crops and animals since } \\
\text { they are not getting enough water to } \\
\text { survive" }\end{array}$ & $\begin{array}{l}\text { Travel long distances } \\
\text { in search of water. } \\
\text { Low crop } \\
\text { productivity. }\end{array}$ & $\begin{array}{l}\text { No water for dry } \\
\text { season farming. } \\
\text { Low } \\
\text { productivity. }\end{array}$ \\
\hline $\begin{array}{l}\text { Increased } \\
\text { flooding }\end{array}$ & $\begin{array}{l}\text { "Flooding of our farmlands has } \\
\text { increased and is now an annual } \\
\text { phenomenon. When it floods, our } \\
\text { crops, animals and other properties } \\
\text { get destroyed" }\end{array}$ & Destruction of crops. & $\begin{array}{l}\text { Destruction of maize } \\
\text { crops. }\end{array}$ \\
\hline
\end{tabular}

Source: Transcription of FGDs (2021)

\section{Conclusions and Policy Implications}

The adverse impacts of climate change pose a threat to the agriculture sector, especially for rainfed farming systems. Increasing awareness of farmers about climatic events presents a significant step in combating climate threats. Migration is one of the adaptation strategies 
adopted by farmers in response to climate events in Ghana. Using a cross-sectional research design, the study collected qualitative and quantitative data from households in five regions of Ghana. This study assessed the perception of smallholder farmers about climate change using key informants' interviews and focus group discussions. Also, the study analysed the impact of climate perception and migration on productivity of maize farmers in Ghana using the Heckman sample selection model. Estimates from the productivity function in the Heckman sample selection model show that experience in maize farming, access to farm credit, farm size, location, the quantity of NPK, and quantity of local seeds have a positive effect on productivity, while the quantity of improved seeds and family labour has a negative and significant relationship with productivity.

Also, the results of the study show that perception of soil fertility; perception of drought, perception of pests, and disease and perception of floods have no significant effect on productivity. Additionally, the study found that household size, main occupation, membership of FBO, and perception of soil fertility have significant effects on migration decisions of smallholder maize farmers. The focus group discussion and key informant interview reports show that four extreme weather events are perceived to have changed. These include an increase in temperature, prolonged drought, increased flooding, and irregular rainfall pattern. These extreme weather events have significantly impacted productivity as well as the social and economic life of smallholder maize farmers.

The study recommends the modernisation of indigenous agricultural practices, promoting the use of improved seeds, and nitrogen, phosphorus and potassium fertilizer coupled with the provision of farm credit and expansion of farm size should be pursued to enhance and sustain productivity among smallholder maize farmers in Ghana. Migration as an adaptation strategy could also be a maladaptation, as such; smallholder farmers should be supported to engage in other livelihood opportunities, join farmer-based organisations and adopt techniques that improves soil fertility to reduce climate related migration among maize farmers. Capacity building as highlighted in the Ghana national climate change policy should be pursued at the local level to improve farmers' adaptive capacity to changes in extreme weather conditions. Also, short term adaptation strategies such as livelihood support opportunities should be provided to farmers to mitigate the impact of extreme weather events on productivity. In addition, long term adaptation strategies that sustain or enhance productivity should be pursued.

\section{Acknowledgement}

The research of this article was supported by DAAD within the framework of the climapAfrica programme with funds of the Federal Ministry of Education and Research. The authors/publisher is fully responsible for the content.

\section{Conflict of interest}

The authors have no conflict of interest. 


\section{References}

Abdulai, J., Nimoh, F., Darko-Koomson, S., \& Kassoh, K. F. S. (2017). Performance of vegetable production and marketing in peri-urban Kumasi, Ghana. Journal of Agricultural Science, 9(3), 202. https://doi.org/10.5539/jas.v9n3p202

Abdulai, S., Nkegbe, P.K., \& Donkoh, S. A. (2018). Assessing the technical efficiency of maize production in northern Ghana: The data envelopment analysis approach. Cogent Food and Agriculture, 4, 1512390. https://doi.org/10.1080/23311932.2018.1512390

Abro, Z. A., Debela B. L., \& Kassie, M. (2019). The joint impact of improved maize seeds on productivity and efficiency: implications for policy. Global Food Discussion Paper 128, University of Goettingen. http://www.uni-goettingen.de/de/213486.html

Adimassu, Z., Kessler, A., \& Stroosnijder, L. (2014). Farmers' strategies to perceive trends of rainfall and crop productivity in the Central Rift Valley of Ethiopia. Environmental Development, 11, 123-140. https://doi.org/10.1016/j.envdev.2014.04.004

Adzawla, W., \& Alhassan, H. (2021). Effects of climate adaptation on technical efficiency of maize production in Northern Ghana. Agric Econ., 9, 14. https://doi.org/10.1186/s40100-021-00183-7

Adzawla, W., Azumah, S. B., Anani, P. Y., \& Donkoh, S. A. (2019). Gender perspectives of climate change adaptation in two selected districts of Ghana. Heliyon, 5(11), e02854. https://doi.org/10.1016/j.heliyon.2019.e02854

Ali, I., Huo, X., Khan, I., Ali, H., Khan, B., \& Khan, S. U. (2019). Technical efficiency of hybrid maize growers: A stochastic frontier model approach. Journal of Integrative Agriculture, 18(10), 2408-2421. https://doi:10.1016/S2095-3119(19)62743-7

Anang, B. T. (2019). Are Adopters of Improved Rice Varieties More Productive than non-Adopters? Empirical Evidence from Northern Ghana. Ghana Journal of Development Studies, 16(1), 92-107. https://doi.org/10.4314/GJDS.V16I1.5

Antwi-Agyei, P., \& Nyantakyi-Frimpong, H. (2021). Evidence of Climate Change Coping and Adaptation Practices by Smallholder Farmers in Northern Ghana. Sustainability, 13, 1308. https://doi.org/10.3390/su13031308

Antwi-Agyei, P., Stringer, L. C., \& Dougill, A. J. (2014). Livelihood adaptation to climate variability: insights from farming households in Ghana. Regional Environmental Change, 14, 1615-1626. https://doi.org/10.1007/s10113-014-0597-9

Asante, F. A., \& Amuakwa-Mensah, F. (2015). Climate change and variability in Ghana: Stocktaking. Climate, 3(1), 78-99. https://doi.org/10.3390/cli3010078

Azumah, S. B., Adzawla, W., Donkoh, S. A., \& Anani, P. Y. (2021). Effects of climate adaptation on households' livelihood vulnerability in South Tongu and Zabzugu districts of Ghana, Climate and Development, 13(3), 256-267. https://doi.org/10.1080/17565529.2020.1757398 
Bardsley, D. K., \& Hugo, G. J. (2010). Migration and climate change: examining thresholds of change to guide effective adaptation decision-making. Population and Environment, 32, 238-262. https://doi.org/10.1007/s11111-010-0126-9

Bawakyillenuo, S., Yaro, J. A., \& Teye, J. (2016). Exploring the autonomous adaptation strategies to climate change and climate variability in selected villages in the rural northern savannah zone of Ghana. Local Environment, 21, 361-382. https://doi.org/10.1080/13549839.2014.965671

Belete, A. S. (2020). Analysis of technical efficiency in maize production in Guji Zone: stochastic frontier model. Agriculture and Food Security, 9, 15. https://doi.org/10.1186/s40066-020-00270-w

Bezu, S., Kassie, G. T., Shiferaw, B., \& Ricker-Gilbert, J. (2014). Impact of improved maize adoption on welfare of farm households in Malawi: a panel data analysis. World Development, 59, 120-131. https://doi.org/10.1016/j.worlddev.2014.01.023

Bua, S., El Mejahed, K., MacCarthy, D., Adogoba, D. S., Kissiedu, I. N., Attakora, W. K., Fosu, M., \& Bindraban, P. S. (2020). Yield responses of maize to fertilizer in Ghana. IFDC FERARI Research report No.2.

Codjoe, S. N. A., Owusu, G., \& Burkett, V. (2014). Perception, experience, and indigenous knowledge of climate change and variability: the case of Accra, a Sub-Saharan African city. Reg. Environ. Change, 14, 369-383. https://doi.org/10.1007/s10113-013-0500-0

Deressa, T. T., Hassan, R. M., Ringler, C., Alemu, T., \& Yusuf, M. (2009). Determinants of farmers' choice of adaptation methods to climate change in the Nile Basin of Ethiopia. Global Environmental Change, 19(2), 248-255.https://doi.org/10.1016/j.gloenvcha.2009.01.002

Di Falco, S. (2014). Adaptation to climate change in sub-Saharan agriculture: assessing the evidence and rethinking the drivers. Eur Rev Agric Econ., 41, 405-430. https://doi.org/10.1093/erae/jbu014

El-Sanatawy, A.M., El-Kholy, A. S. M., Ali, M. M. A., Awad, M. F., \& Mansour, E. (2021). Maize Seedling Establishment, Grain Yield and Crop Water Productivity Response to Seed Priming and Irrigation Management in a Mediterranean Arid Environment. Agronomy, 11, 756. https://doi.org/10.3390/agronomy11040756

Evenson, R. E., \& Gollin, D. (2003). Crop variety improvement and its effect on productivity: the impact of international agricultural research, Cabi publishing: Wallingford (UK). https://doi.org/10.1079/9780851995496.0000

Fisher, M., Abate, T., Lunduka, R. W., Asnake, W., Alemayehu, Y., \& Madulu, R. B. (2015). Drought tolerant maize for farmer adaptation to drought in sub-Saharan Africa: determinants of adoption in eastern and southern Africa. Climate Change, 133, 283-299. https://doi.org/10.1007/s10584-015-1459-2 
Food and Agriculture Organization of the United Nations, (2017). Migration, Agriculture and Climate Change: Reducing Vulnerabilities and Enhancing Resilience (available on https://reliefweb.int)

Gbangou, T., Ludwig, F., van Slobbe, E., Greuell, W., \& Kranjac-Berisavljevic, G. (2020). Rainfall and dry spell occurrence in Ghana: trends and seasonal predictions with a dynamical and a statistical model. Theoretical and Applied Climatology, 141, 371-387. https://doi.org/10.1007/s00704-020-03212-5

Gebre, G. G., Isoda, H., Rahut, D. B., Amekawa, Y., \& Nomura, H. (2021). Gender differences in agricultural productivity: evidence from maize farm households in southern Ethiopia. GeoJournal, 86, 843-864. https://doi.org/10.1007/s10708-019-10098-y

Ghana Statistical Service (GSS) (2013). 2010 Population and Housing Census. Non-Monetary Poverty in Ghana. Ghana Statistical Service, Accra, Ghana. July 2013. http://www.statsghana.gov.gh/

Ghana Statistical Service (GSS) (2021). 2021 Population and Housing Census of Ghana. Statistical Service, Accra, Ghana. http://www.statsghana.gov.gh/

Heckman, J. (1976). The Common Structure of Statistical Models of Truncation, Sample Selection and Limited Dependent Variables and a Simple Estimator for Such Models". Annals of Economic and Social Measurement, 5(4), 475-492.

Jarawura, F. X. (2013). Drought and Migration in Northern Ghana. Doctoral dissertation, Center for Migration Studies, University of Ghana. Accra, Ghana. www.ugspace.ug.edu.gh

Kallio, E. (2016). Human Migration: Implications and Opportunities for Conservation. Working Paper 4. Yale School of Forestry and Environmental Studies.

Kassa, T., \& Mogiso, M. (2020). Assessment of improved crop seed utilization status in selected districts of Southwestern Ethiopia, Cogent Food and Agriculture, 6(1), 1816252. https://doi.org/10.1080/23311932.2020.1816252

Khanal, U., Wilson, C., Lee, B., \& Hoang, V. N. (2018). Do climate change adaptation practices improve technical efficiency of smallholder farmers? Evidence from Nepal. Climatic Change, 147, 507-521. https://doi.org/ https://doi.org/10.1007/s10584-018-2168-4

Khonje, M., Manda, J., Alene, A. D., \& Kassie, M. (2015). Analysis of adoption and impacts of improved maize varieties in Eastern Zambia. World Development, 66, 695-706. https://doi.org/10.1016/j.worlddev.2014.09.008

Kok, P., O’Donovan, M., Bouare, O., \& Van Zyl, J. (2003). Post-apartheid patterns of internal migration in South Africa. Cape Town: HSRC.

Konja, D. T., Mabe, F. N., \& Alhassan, H. (2019). Technical and resource-use-efficiency among smallholder rice farmers in Northern Ghana, Cogent Food and Agriculture, 5(1), 1651473. https://doi.org/10.1080/23311932.2019.1651473 
Lin, L., Wang, W., Gan, C., \&Nguyen, Q. T. T. (2019). Credit constraints on farm household welfare in rural China: evidence from Fujian Province. Sustainability, 11(11), 1-19. https://doi.org/10.3390/su11113221

Mabe, F. N., Donkoh, S. A., \& Al-hassan, S. (2018). Accounting for rice productivity heterogeneity in Ghana: The two-step stochastic metafrontier approach. International Journal of Agricultural and Biosystems Engineering, 12(8), 223-232. https://doi.org/10.1999/1307-6892/10009379

Maddison, D. (2007). The Perception of and Adaptation to Climate Change in Africa; The World Bank: Washington, DC, USA.

https://openknowledge.worldbank.org/handle/10986/7507 License: CC BY 3.0 IGO. https://doi.org/10.1596/1813-9450-4308

Manda, J., Alene, A. D., Gardebroek, C., Kassie, M., \& Tembo, G. (2016). Adoption and impacts of sustainable agricultural practices on maize yields and incomes: evidence from Rural Zambia. Journal of Agricultural Economics, 67(1), 130-153.

https://doi.org/10.1111/1477-9552.12127

Meughoyi, C. T. (2018). Improved Seeds and Agricultural Productivity of Family Farms in Cameroon. In Building a Resilient and Sustainable Agriculture in Sub-Saharan Africa, edited by A. Shimeles, A. Verdier-Chouchane, and A. Boly, Cham, Switzerland. 15-32. https://doi.org/10.1007/978-3-319-76222-7_2

Mihi-Ramirez, A., \& Kumpikaite, V. (2014). Economics reasons for migration from the point of view of students. Procedia - Social and Behavioral Sciences, 109, 522-526. https://doi.org/10.1016/j.sbspro.2013.12.500

Mwalupaso, G. E., Wang, S., Rahman, S., Alavo, E. J. P., \& Tian, X. (2019). Agricultural Informatization and Technical Efficiency in Maize Production in Zambia. Sustainability, 11, 2451. https://doi.org/10.3390/su11082451

Nelson, G. C., Rosegrant, M. W., Koo, J., Robertson, R., Sulser, T., Zhu, T., ... \& Lee, D. (2009). Climate Change: Impact on Agriculture and Costs of Adaptation. IFPRI Food Policy Report, Washington DC.

Ngango, J., \& Hong, S. (2021). Improving farm productivity through the reduction of managerial and technology gaps among farmers in Rwanda. Agriculture and Food Security, 10, 11. https://doi.org/10.1186/s40066-020-00284-4

Niang, I., Ruppel, O.C., Abdrabo, M.A., Essel, A., Lennard, C., Padgham, J., \& Urquhart, P. (2014). Africa. In: Climate change 2014: impacts, adaptation and vulnerability. Contribution of Working Group II to the Fifth Assessment Report of the Intergovernmental Panel on Climate Change. Cambridge University Press, Cambridge.

Nicholas, F., Dugle, G., \& Darius, T. M. (2017). Migration as an Adaptation Strategy to Climate Change: Influencing Factors in North-western Ghana. Journal of Sustainable Development, 10(6), 155-168. https://doi.org/10.5539/jsd.v10n6p155 
Orlove, B., Roncoli, C., Kabugo, M., \& Majugu, A. (2010). Indigenous climate knowledge in southern Uganda: The multiple components of a dynamic regional system. Climate Change, 100, 243-265. https://doi.org/10.1007/s10584-009-9586-2

Oyetunde-Usman, Z., \& Olagunju, K.O. (2019). Determinants of Food Security and Technical Efficiency among Agricultural Households in Nigeria. Economies, 7, 103. https://doi.org/10.3390/economies7040103

Roco, L., Bravo-Ureta, B., Engler, A., \& Jara-Rojas, R. (2017). The impact of climatic change adaptation on agricultural productivity in Central Chile: a stochastic production frontier approach. Sustainability, 9(9), 1648. https://doi.org/10.3390/su9091648

Sapkota, M., \& Joshi, N. P. (2021). Factors Associated with the Technical Efficiency of Maize Seed Production in the Mid-Hills of Nepal: Empirical Analysis. International Journal of Agronomy. https://doi.org/10.1155/2021/5542024

Scheiterle, L., \& Birner, R. (2018). Assessment of Ghana's Comparative Advantage in Maize Production and the Role of Fertilizers. Sustainability, 10, 4181. https://doi.org/10.3390/su10114181

Scheiterle, L., Häring, V., Birner, R., \& Bosch, C. (2019). Soil, Striga, or subsidies? Determinants of maize productivity in northern Ghana. Agricultural Economics. 50, 479-494. https://doi.org/10.1111/agec.12504

Siaw, A., Jiang, Y., Ankrah Twumasi, M., Agbenyo, W., Ntim-Amo, G., Osei Danquah, F., \& Ankrah, E. K. (2021). The ripple effect of credit accessibility on the technical efficiency of maize farmers in Ghana. Agricultural Finance Review, 81(2), 189-203. https://doi.org/10.1108/AFR-05-2020-0068

Snaibi, W., Mezrhab, A., Sy, O., \& Morton, J. (2021). Perception and adaptation of pastoralists to climate variability and change in Morocco's arid rangelands. Heliyon, e08434, https://doi.org/10.1016/j.heliyon.2021.e08434

Srivastava, A. K., Mboh, C. M., Zhao, G., Gaiser, T., \& Ewert, F. (2018). Climate change impact under alternate realizations of climate scenarios on maize yield and biomass in Ghana. Agricultural systems, 159, 157-174. https://doi.org/10.1016/j.agsy.2017.03.011

Suri, T. (2011). Selection and Comparative Advantage in Technology Adoption. Econometrica, 79(1), 159-209. https://doi.org/10.3982/ECTA7749

Sutcliffe, C., Dougill, A. J., \& Quinn, C. H. (2016). Evidence and perceptions of rainfall change in Malawi: Do maize cultivar choices enhance climate change adaptation in sub-Saharan Africa? Regional Environmental Change, 16, 1215-1224. https://doi.org/10.1007/s10113-015-0842-X

Teklewold, H., Kassie, M., \& Shiferaw, B. (2013). Adoption of Multiple Sustainable Agricultural Practices in Rural Ethiopia'. Journal of Agricultural Economics, 64(3), 597-623. https://doi.org/10.1111/1477-9552.12011 


\section{Macrothink}

Journal of Agricultural Studies

ISSN 2166-0379 2022, Vol. 10, No. 1

Toungos, M. D. (2019). Effect of Organic and Inorganic Fertilizers on Yield of Maize in Mubi North Local Government Area, Adamawa State, Nigeria. International Journal of Innovative Agriculture and Biology Research, $7(2)$ 26-35. http://seahipaj.org/journals-ci/june-2019/IJIABR/full/IJIABR-J-4-2019.pdf

Ugbagbe, O. O., Abdoulaye, T., Kamara, A. Y., Mbavai, J., \& Oyinbo, O. (2017). Profitability and Technical Efficiency of soybean production in Northern Nigeria. Tropicultura, 35, 203-214. https://hdl.handle.net/10568/89022

Waldinger, M., \& Fankhauser, S. (2015). Climate change and migration in developing countries: evidence and implications for PRISE countries: Grantham Research Institute on Climate Change and the Environment. http://creativecommons.org/licenses/by/4.0/legalcode

Walker, T. S., \& Alwang, J. (2015). Crop Improvement, Adoption and Impact of Improved Varieties in Food Crops in Sub-Saharan Africa, CABI: Wallingford. https://doi.org/10.1079/9781780644011.0000

Williams, P. A., Crespo, O., \& Abu, M. (2019). Adapting to changing climate through improving adaptive capacity at the local level-The case of smallholder horticultural producers in Ghana. Climate Risk Management, 23, 124-135. https://doi.org/10.1016/j.crm.2018.12.004

\section{Copyright Disclaimer}

Copyright for this article is retained by the author(s), with first publication rights granted to the journal.

This is an open-access article distributed under the terms and conditions of the Creative Commons Attribution license (http://creativecommons.org/licenses/by/4.0/). 